Theories \& Applications, the International Edition

Printed Version: (ISSN 2090-5262)

Online Version: (ISSN 2090-5270)

November 2013, Volume 3, No. 3 Pages (115 - 121)

\title{
An Analysis of the Use of Proprioceptive Neuromuscular Facilitated Stretching Methods on Explosive Strength Performance in Wrestling
}

\author{
Ayman Muslim Sulaiman*
}

\begin{abstract}
This paper is trying to analyze how proprioceptive neuromuscular facilitation (PNF) methods can improve muscular diastolic capacity. The research aims to identify the effect of using one of PNF method (Hold - Relax with agonist contraction) on explosive strength for wrestlers, and the Efficiency of the Reverse Body Lift skill performance for 16 volunteered healthy male wrestlers. Subjects classified into two Groups: Experimental and Control Group. Results reveal that postmeasurement of 3 times of Bridge up test ( $\mathrm{Sec}$ ) significantly decreased $(7.17 \pm 0.33,6.4 \pm 0.37$ ) for post and pre-measurements respectively. Flexible of spine $(\mathrm{cm})$ significantly decreased $(22.3 \pm 0.93$, $20.57 \pm 1.01)$ for post and pre-measurements respectively, with improvement percentage of (7.09\%) .Vertical distance (cm) significantly increased $(18.61 \pm 0.90,20.33 \pm 1.02)$ for pre and postmeasurements respectively, with improvement percentage of (8.46\%). Explosive strength (Sec) significantly decreased $(13.61 \pm 1.41,11.7 \pm 0.71)$ for post and pre-measurements respectively, with improvement percentage of (14.03\%). Reverse Body Lift skill (cm) significantly increased (6.03 \pm $0.57,7.76 \pm 0.97)$ for pre and post-measurements respectively, with improvement percentage of (22.29\%), the most important conclusion was that applying training program that contains PNF exercises lead to an improvement of all physical variables, and led to the significant improvement in performance.
\end{abstract}

\section{Introduction}

$\mathrm{D}$ eveloping wrestling sport technical performance is related to many Sciences such as anatomy, physiology, mechanics; which contribute significantly to improve joints movement range. That may lead to development of speed performance, explosive power and reduce muscle injuries during the process of stretching or flexibility motor range allowed by muscle or joint according to skill technical performance requirements. (Saleh Abdelejaber, 2008: p4).

The Reverse Body Lift skill is an important skill; which is executed in ground wrestling position, and gives a good opportunity for attacker wrestler to lose the defender his

* Lecturer, Department of Athletic Training and Athletic Kinetic Science, Faculty of Physical Education, Assiut University, Egypt. balance. So it became easy to hook him, and award points, also to execute shoulders touch. (Mohamed El-Ruby, 2005:p128)

The wrestling experts in FILA modified the wrestling rules and give much interest in the Reverse Body Lift skill, that where if a round ends without a win for either wrestlers. The wrestler with fewest points is in the ground position of the defending wrestler and the other one is the attacked wrestler. He tries to control the defending wrestler in the Reverse Body Lift skill, and if he does not execute this action or other during 30 seconds; the defending wrestler will award 1 point to resist the attacked wrestler and give him no opportunity to execute the action; then wrestlers exchange attacker and defender positions. That emphasize the importance of Reverse Body Lift skill training and find exercises to enhance the efficiency of wrestler's muscles, to perform the skill efficiently, also to achieve shoulders touching or awarded high points. 
Stretching has long been touted as an important adjunct to a physical fitness program, and a variety of stretching techniques exist to enhance flexibility and range of motion (ROM). However, debate exists as to the type of stretching that should be included. Traditionally, static stretching has been performed prior to competition; however, there is evidence in the literature that static stretching may have a detrimental effect on sports performance (Fletcher, 2010, p2097, Gelen E., 2010, p951). Static stretching is a type of stretch that involves holding a stretch at the end position for 30 seconds and includes both relaxation and concurrent elongation of the stretched muscle (3). More recently, dynamic stretching has been proposed to be a better method of stretching prior to competition and has been shown to have a positive or neutral impact on performance (Gelen E., 2010, p951). Dynamic stretching is a type of stretching that involves sport-specific movements to prepare the athlete for activity (National Strength and Conditioning Association, 2008)). Both dynamic and static stretching have the advantage of being performed individually, however they may not elicit the greater gains in range of motion (ROM).

Proprioceptive Neuromuscular Facilitated (PNF) stretching is also a common mode of stretching. PNF stretching techniques are commonly used in both athletic and clinical settings to enhance both active and passive ROM to optimize motor performance and rehabilitation (Sharman MJ et al , 2006, p931). While static, ballistic, dynamic, and PNF stretching are all effective at enhancing joint ROM, PNF stretching produces a greater enhancement (Ferber R, 2006, p393, Funk DC et al, 2003, p491). PNF stretching is thought to be superior to other stretching methods because it facilitates muscular inhibition. PNF stretching involves three specific muscle actions to facilitate the passive stretch (National Strength and Conditioning Association, 2008.).

\section{Research Objectives}

The research aims to identify the effect of using one of PNF method (Hold - Relax with agonist contraction) on explosive strength for wrestlers, and the Efficiency of the Reverse Body Lift skill performance for wrestlers

\section{Material and Methods}

\section{Subjects}

16 volunteered healthy male wrestler, aged $19 \pm$ 0.69 years, height $163.3 \pm 6.8 \mathrm{~m}$ and weight $58.87 \pm 6.05 \mathrm{~kg}$. They have $6.62 \pm 1.24$ Training Age. Subjects classified to two equal groups: Experimental and Control Group.

\section{Protocol}

After homogeneity between the two groups was confirmed, Subjects were tested pre and post program implantation in Five Measurements (Flexible of spine, 3 time of bridge up test performance, Vertical distance, Explosive strength, Efficiency of Reverse Body Lift skill performance). The researcher conducted an implementation of the proposed exercise from June 9th, 2012 until August 1st, 2012.

\section{Data analysis}

$\mathrm{T}$ test was used to determine significance of differences between pre and post-measurements of variables under discussion. Researcher adopted 0.05 significance level while analyzing data.

\section{Tools}

Medical scales to measure weight in kilograms, Dynamometer to measure grip strength, strength of legs and back muscles, Stopwatch, Goniometer to measure motor spine motor range, Wrestling mat to execute the training program and physical and fitness tests, measure tape to measure height bridge vertical distance 
Table (1)

Measurements of basic, physical and Skills variables before PNF Program for Experimental and Control group Subjects.

\begin{tabular}{|c|c|c|c|c|c|c|c|}
\hline \multirow{2}{*}{$\begin{array}{c}\text { Measurements } \\
\text { Variables }\end{array}$} & \multirow{2}{*}{$\begin{array}{l}\text { Measurement } \\
\text { Unit }\end{array}$} & \multicolumn{2}{|c|}{$\begin{array}{l}\text { Experimental group } \\
(\mathrm{n}=8)\end{array}$} & \multicolumn{2}{|c|}{$\begin{array}{l}\text { control group } \\
(\mathrm{n}=8)\end{array}$} & \multirow[t]{2}{*}{ T-test } & \multirow[t]{2}{*}{ Level of significance } \\
\hline & & Mean & $\pm \mathrm{SD}$ & Mean & $\pm \mathrm{SD}$ & & \\
\hline Age & Year & 18.96 & 0.69 & 19.15 & 0.66 & 0.09 & \multirow{9}{*}{ 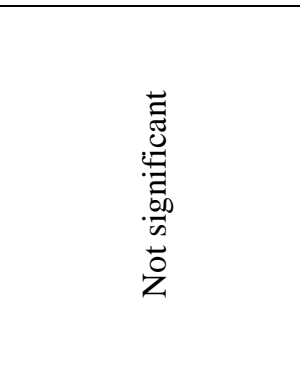 } \\
\hline Training age & Year & 6.62 & 1.24 & 6.7 & 0.80 & 0.40 & \\
\hline Weight & $\mathrm{Kg}$ & 58087 & 6.85 & 59.5 & 6.34 & 0.16 & \\
\hline Length & $\mathrm{Cm}$ & 163.37 & 6.80 & 162.62 & 6.04 & 0.33 & \\
\hline 3 time of Bridge up test & Sec & 7.17 & 0.37 & 7.02 & 0.42 & 0.43 & \\
\hline Flexible of spine & $\mathrm{Cm}$ & 22.03 & 0.93 & 22.13 & 0.86 & 0.24 & \\
\hline Vertical distance & $\mathrm{Cm}$ & 18.61 & 0.90 & 18.41 & 0.81 & 0.01 & \\
\hline Explosive strength & $\mathrm{Sec}$ & 13.61 & 0.41 & 14.13 & 0.40 & 0.01 & \\
\hline The Reverse Body Lift skill & Num & 5.77 & 0.35 & 5.91 & 0.32 & 0.21 & \\
\hline
\end{tabular}

\section{T significance at 0.05 level $=2.145$}

Table (1) results reveal no significant before experiments which confirm homogeneity differences between experimental and control between the two groups group in basic, physical and skill variables

Results

Table (2)

Differences of physical and Skills variables between before and after PNF Program for Experimental group Subjects. $(n=8)$

\begin{tabular}{|c|c|c|c|c|c|c|}
\hline Measurements Variables & $\begin{array}{c}\text { Measurement } \\
\text { unit }\end{array}$ & $\begin{array}{c}\text { Pre } \\
(\text { Mean } \pm \\
\text { SD) }\end{array}$ & $\begin{array}{c}\text { Post } \\
(\text { Mean } \pm \\
\text { SD) }\end{array}$ & $\begin{array}{l}\text { Improvement } \\
\text { percentage }\end{array}$ & $\begin{array}{l}\mathrm{T}- \\
\text { test }\end{array}$ & $\begin{array}{c}\text { Level of } \\
\text { significance }\end{array}$ \\
\hline 3 time of Bridge up test & Sec & $7.17 \pm 0.33$ & $6.4 \pm 0.37$ & 10.73 & 6.93 & \multirow{5}{*}{ : } \\
\hline Flexible of spine & $\mathrm{cm}$ & $22.3 \pm 0.93$ & $20.57 \pm 1.01$ & 7.09 & 7.81 & \\
\hline Vertical distance & $\mathrm{cm}$ & $18.61 \pm 0.90$ & $20.33 \pm 1.02$ & 8.46 & 7.80 & \\
\hline Explosive strength & $\mathrm{Sec}$ & $13.61 \pm 1.41$ & $11.7 \pm 0.71$ & 14.03 & 7.83 & \\
\hline $\begin{array}{c}\text { The Reverse Body Lift } \\
\text { skill }\end{array}$ & Num & $6.03 \pm 0.57$ & $7.76 \pm 0.97$ & 22.29 & 9.95 & \\
\hline
\end{tabular}

T significance at 0.05 level $=2.365$

Figure (1)

Variables measurements before and after PNF Program for Experimental group Subject

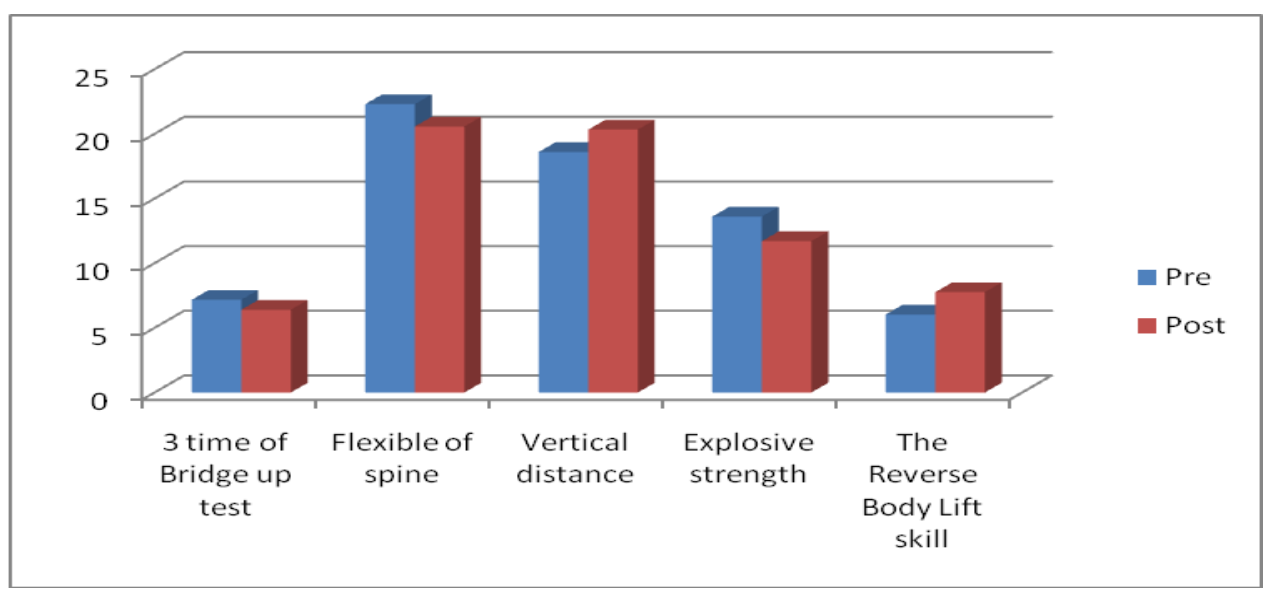

Table (2) ND figure (1) reveal significant differences in physical and Skills variables before and after PNF Program for Experimental group Subjects: The 3 time of Bridge up test (Sec) significantly decreased after PNF Program
$(7.17 \pm 0.33,6.4 \pm 0.37 \mathrm{p}<0.05)$. The Flexible of spine $(\mathrm{cm})$ significantly decreased after PNF Program $(22.3 \pm 0.93,20.57 \pm 1.01(\mathrm{p}<0.05)$, with improvement percentage $(7.09 \%) \quad(\mathrm{p}<$ $0.05)$.The Vertical distance $(\mathrm{cm})$ significantly 
Increased after PNF Program (18.61 \pm 0.90 , $20.33 \pm 1.02(\mathrm{p}<0.05)$, with improvement percentage $(8.46 \%) \quad(\mathrm{p}<0.05)$.The Explosive strength (Sec) significantly decreased after PNF Program $(13.61 \pm 1.41,11.7 \pm 0.71(\mathrm{p}<0.05)$, with improvement percentage (14.03\%) (p < 0.05).The The Reverse Body Lift skill $(\mathrm{cm})$ significantly increased after PNF Program (6.03 $\pm 0.57, \quad 7.76 \pm 0.97 \quad(\mathrm{p}<0.05)$, with improvement percentage $(22.29 \%) \quad(\mathrm{p}<0.05)$.

Table (3)

Differences of physical and Skills variables after PNF Program between Experimental and control group Subjects. $(n=8)$

\begin{tabular}{|c|c|c|c|c|c|c|}
\hline $\begin{array}{l}\text { Measurements } \\
\text { Variables }\end{array}$ & $\begin{array}{c}\text { Measurement } \\
\text { unit }\end{array}$ & $\begin{array}{c}\text { control } \\
\text { group } \\
n=8 \\
(\text { Mean } \pm \text { SD) }\end{array}$ & $\begin{array}{c}\text { Experimental } \\
\text { group } \\
n=8 \\
\text { (Mean } \pm \text { SD) }\end{array}$ & $\begin{array}{l}\text { The } \\
\text { difference }\end{array}$ & $\begin{array}{c}\mathrm{T}- \\
\text { test }\end{array}$ & $\begin{array}{c}\text { Level of } \\
\text { significance }\end{array}$ \\
\hline $\begin{array}{c}3 \text { time of Bridge up } \\
\text { test }\end{array}$ & $\mathrm{sec}$ & $7.25 \pm 0.38$ & $6.4 \pm 0.37$ & 0.85 & 9.58 & \multirow{5}{*}{ 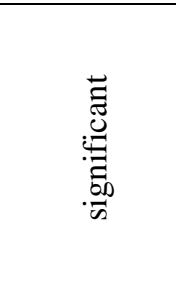 } \\
\hline Flexible of spine & $\mathrm{cm}$ & $22.67 \pm 0.91$ & $20.57 \pm 1.01$ & 2.1 & 6.05 & \\
\hline Vertical distance & $\mathrm{cm}$ & $18.83 \pm 0.69$ & $20.33 \pm 1.02$ & 1.5 & 4.64 & \\
\hline Explosive strength & $\mathrm{Sec}$ & $13.15 \pm 0.88$ & $11.7 \pm 0.71$ & 1.38 & 8.70 & \\
\hline $\begin{array}{l}\text { the Reverse Body Lift } \\
\text { skill }\end{array}$ & Num & $6.7 \pm 1.40$ & $7.76 \pm 0.97$ & 1.94 & 8.04 & \\
\hline
\end{tabular}

T significance at 0.05 level $=2.145$

Figure (2)

Variables measurements before and after PNF Program for Experimental and Control group Subject

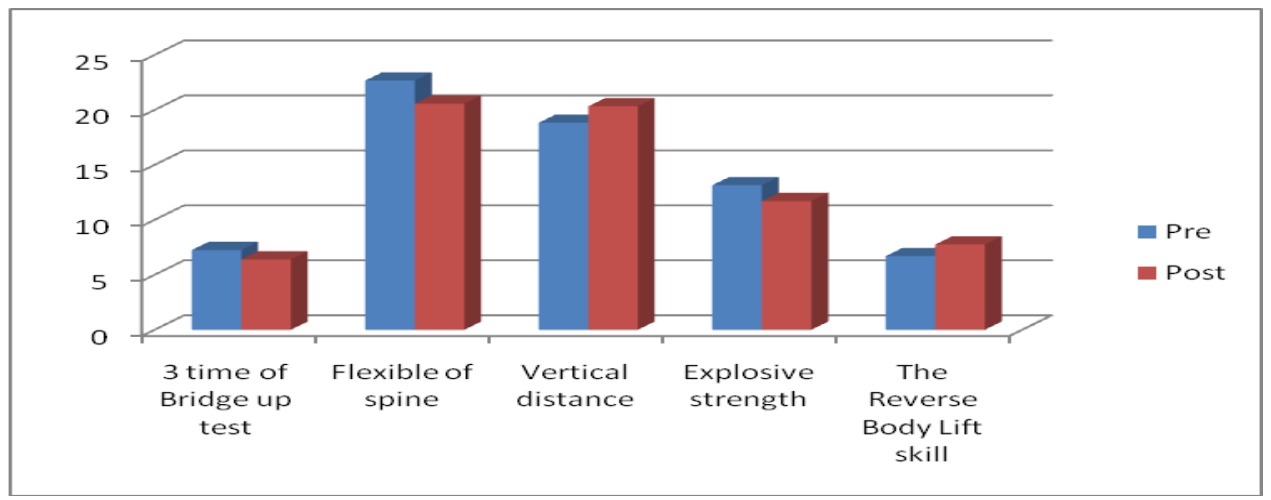

Table (3) and figure (2) show significant differences in physical and Skills variables after PNF Program between Experimental and Control group Subjects : The 3 time of Bridge up test $(\mathrm{Sec})$ significantly decreased after PNF Program for $(7.25 \pm 0.38,6.4 \pm 0.37 \mathrm{p}<0.05)$, and The difference $(0.85)(\mathrm{p}<0.05)$. The Flexible of spine $(\mathrm{cm})$ significantly decreased after PNF Program (22.67 $\pm 0.91,20.57 \pm 1.01$ (p $<0.05)$, and The difference $(2.1)(\mathrm{p}<0.05)$. The Vertical distance $(\mathrm{cm})$ significantly Increased after PNF Program $(18.83 \pm 0.69,20.33 \pm 1.02$ $(\mathrm{p}<0.05)$, and The difference $(1.5)(\mathrm{p}<0.05)$. The Explosive strength $(\mathrm{Sec})$ significantly decreased after PNF Program $(13.15 \pm 0.88,11.7$ $\pm 0.71(\mathrm{p}<0.05)$, and The difference (1.38) (p $<0.05)$. The Reverse Body Lift skill $(\mathrm{cm})$ significantly Increased after PNF Program $(6.7 \pm 1.40,7.76 \pm 0.97 \quad(\mathrm{p}<0.05)$, and The difference (1.94) $(\mathrm{p}<0.05)$.

\section{Discussion}

Results in this study revealed presence of differences pre and post PNF Program in physical and Skills variables for Experimental group subjects. (Figure 1 and 2). Bridge up test time decreased to about 3 times with improvement percentage $(10.73 \%)$. There was also significant differences between Experimental and Control group in Bridge up test time with difference about (0.85) after PNF training program, Bridge up skill speed has been improved, which mean that muscles can work faster, which in turn allow wrestler to perform this skill more speedy as possible without fatigue (Edward David, 1991: pp301- 312), (Chao- chung, 2003:p5),(Mohamed ElRuby,2005 128), (McNeal 2006: p141-146) 
Results also revealed significant decrease spine flexibility with improvement percentage (7.09), and difference between Experimental and Control group in spine flexibility with difference of (2.1). there was also increase in vertical distance variable between pre and post tests for Experimental group with improvement percentage improvement (8.46), There was also significant difference between Experimental and control group of (1.5). Stretching exercises have been considered an essential component of physical training programs for decades, studies have demonstrated that flexibility measures are related to performance for wrestler. More flexibility is acquired after PNF Program. Much flexibility needed each day, from bending over to tie our shoes to wrestling off tight, sweaty sports bras. It's these small tasks that often challenge our flexibility the most, (Abuella 1995: p264), (Bonner Bp, Devers, 2004:p6), (Davis DS,2005:2),(Kofotolis2005:p1), (Herman, 2008: pp 128-129), (Saleh Abdelgaber 2008:p80).

This study's results also revealed presence of significant decrease in Explosive strength test with improvement percentage (14.03); with significant differences between Experimental and Control group in the same test after PNF program with difference (1.38). Successful wrestling requires a combination of power, strength and speed which certainly is an advantage. Wrestle under a weight division, which most competitive wrestling is conducted, need to worry less about size and bulk as long as maximize his weight for specific division. (Edward,1991:pp301- 312),(Amjad, 2002:65)(Saleh, 2004: p90),(wlied, 2004:p70), (Roemmish, 2006:p3).

Study results also reveal existence of significant decrease of Reverse Body Lift skill with improvement percentage (22.29), with differences between Experimental and Control group after PNF program amounted to (1.94). PNF training or Stretching training can enhance athletic characteristics. Because all athletes have individual needs, the best program for an athlete will be modified for his wrestling style, age, goals, and facilities available. However, here's a Stretching program, starting out, which can be used to set up for wrestling competition. This applies to all forms of wrestling including
College, Freestyle, Greco-Roman, and professional wrestling of various types, although professional wrestling often has its own bizarre requirements. (wlied, 2004:pp75100),(Ala Mohammad, 2005:p9), (Ehab, 2008:p93), (Saleh, 2008:p86).

\section{Conclusions}

From the data, information, research results, research sample and through results discussion and interpretation, the researcher concluded that: Applying training program that contains PNF exercises lead to an improvement of all physical variables. PNF exercises that imitate motor skills' performance lead to significant improvement in skills performance (The Reverse Body Lift skill).

\section{Recommendations}

Application of the proposed training program, concerning with individual differences between players when training using PNF exercises (Hold - Relax with agonist contraction) on different skills, considering that training program should simulates the various skills performance.

\section{References}

1. Abuella Abdulfattah, Mohamed Hasssan Alawee,(1995): physiological basics of sport training, Dar Alfeekr Alaraby, Cairo.

2. Alaa Mohammad Qenawi,(2005): the effectiveness of functional power training on some physical variables and the performance of reversal waist skill for young wrestlers, published research, journal of faculty of physical education, Zigzag university.

3. Amjad Zakariya Ahmed Abdel Aal, (2002): the effect of explosive power development on the performance level of skill and some physiological variables of the wrestlers, Master thesis, faculty of physical education for boys, Zigzag university

4. Bonnar Bp, Devers RG, Gould Te, (2004): The relationship between isometric contraction durations during hold - relax stretching \& improvement of hamstring flexibility 
"Department Athletic training services, university of Pittsburgh, PA, USA.

5. Chao- chung lee, Ray - yau wang, yea- Ru yang, (2003): Effects of prospective Neuromuscular facilitation on Balance \& Mobility performance of individuals with chronic stroke. A preliminary report Institute of physical the therapy National yany - Ming university, tapei, Taiwan.

6. Davis SD, Ashoby pe, McCale Kl, McGuain JA, Wine Jm, (2005): the effectiveness of 3 stretching techniques on hamstring flexibility using consistent stretching parameters Department of human performance, west virginia university, Margantown, west Virginia 26505, USA.

7. Edward David, (1991): Research quarterly for exercise \& sport vol. 58. p301- 312.

8. Ehab Hamed Ahmed Barawi, Massad Hassan Mohammed Ahmed, (2008): the impact of using of compound training on the development of muscle strength and effectiveness of the performance of reversal waist skill, the fourth national conference of the international council of health,physical education, recreation and sport for middle east, faculty of physical education for boys, Abu Qir, Alexandria university, V.4,7-15 October.

9. Ferber R, Osternig L, Gravelle D. (2002): Effect of PNF stretch techniques on knee flexor muscle EMG activity in older adults. J Electromyogr Kinesiol 12(5): 391-397.

10. Fletcher IM, Monte-Colombo MM. An (2010): investigation into the effects of different warm-up modalities on specific motor skills related to soccer performance. J Strength Cond Res 24(8): 2096-2101.

11. Funk DC, Swank AM, Mikla BM, Fagan TA, Farr BK.(2003): Impact of prior exercise on hamstring flexibility a comparison of proprioceptive neuromuscular facilitation and static stretching. J Strength Cond Res 17(3): 489-492.

12. Gelen E. (2010): Acute effects of different warm-up methods on sprint, slalom dribbling, and penalty kick performance in soccer players. J Strength Cond Res 24(4): 950-956.
13. Herman, Sonja; Smith, Derek , (2008): Four-Week Dynamic Stretching Warm-up Intervention Elicits Longer-Term Performance Benefits Journal of Strength \& Conditioning Research: Volume 22 - Issue 4 - pp 128-129doi: 10.1519/JSC.0b013e318173da50.

14. Kofotolis N, Vrabas Is, Vamvakidis E, papanikdaou A,Mandroukas K, (2005): prospective Neuromuscular facilitation training induced alterations in muscle fiber type \& cross sectioned area" Department of physical Education \& sports science, Aristotelian University of Thessaloniki, the Salonika Greek.

15. McNeal, Jeni R. PhD; Sands, William A. $\mathrm{PhD}$, (2006): Stretching for Performance Enhancement, urrent Sports Medicine Reports: June 2006 - Volume 5 - Issue 3 - p 141-146 doi: 10.1097/01.CSMR.0000306304.25944.07

Article.

16. Mohamed Reda Hafez El Rubi,(2005): the fundamentals of training in wrestling sport, Alexandria.

17. National Strength and Conditioning Association (2008): Essentials of Strength Training and Conditioning, 3rd ed.. Champaign, IL

18. Roemmish, JN sinning WE,(2006): sport Seasonal changers in body composition growth wrestlers International Journal sports Medicine.

19. Saleh Abdelgaber -Abdullah Al-Hafiz, (2008): the effect of training program using some neuromuscular facilities methods to improve physical variables and the performance (centrums - Burma) skill for young wrestlers, $\mathrm{PhD}$ thesis, faculty of physical education, Assiut University.

20. Saleh Abdel-Jaber -Abdullah Al-Hafiz, (2004): the impact of proposal training program for the improvement of muscular power of (centrums - Burma) skill for young wrestlers, Master thesis, faculty of physical education, Assiut university.

21. Sharman MJ, Cresswell AG, Riek S. (2006): Proprioceptive neuromuscular facilitation stretching : mechanisms and clinical implications. Sports Med 36(11): 929-939, 2006 
22. Wlied Mohsen Mustafa,(2004) :after developing bear distinctive force as fast as some private group movements throw the background on some of the skills and physiological variables for wrestlers 'master of physical education Alexandria university. 